\title{
TITLE:
}

\section{ASEXUAL REPRODUCTION IN AMAROUCIUM YAMAZII (A COLONIAL ASCIDIAN)}

$\operatorname{AUTHOR}(\mathrm{S})$ :

Nakauchi, Mitsuaki

\section{CITATION:}

Nakauchi, Mitsuaki. ASEXUAL REPRODUCTION IN AMAROUCIUM YAMAZII (A COLONIAL ASCIDIAN). PUBLICATIONS OF THE SETO MARINE BIOLOGICAL LABORATORY 1970, 17(5): 309-328

ISSUE DATE:

1970-02-21

URL:

http://hdl.handle.net/2433/175606

RIGHT: 


\title{
ASEXUAL REPRODUCTION IN AMAROUCIUM YAMAZII (A COLONIAL ASCIDIAN)
}

\author{
MITSUAKI NAKAUCHI \\ Department of Biology, Faculty of Literature and Science, Kochi University, Kochi, Japan
}

With 11 Text-figures and Plates XVI-XVII

In the polyclinid ascidians three types of budding are known. The first type, strobilation of the postabdomen, was reported as early as 1874 by KowalevsKy. Thenceforth, for about half a century, this type had been believed to be the only mode of budding in the polyclinid ascidians. In 1925, however, the second type, strobilation of the abdomen proper, was found by BRIEN. In 1966, furthermore, the third type, strobilation of both the abdomen and postabdomen, was added by the present author (Nakauchi, 1966a).

Among these three types the second one is doubly interesting because the process of this budding closely resembles the budding found in the polycitorine ascidians which belong to the family Clavelinidae, and because this type is found in very limited species of the polyclinid ascidians. Only three species are known to propagate by this type. They are Aplidium zostericola (Brien, 1925), Aplidium petrense (Mrllar, 1962), and Amaroucium yamazii (NAKAUGH, 1966a).

As to the morphogenesis in this type of budding a detailed description is given by BRIEN (1925). His description, however, is based upon the observation of preserved materials, so his description is more or less static and qualitative. Millar's description is also based upon a single preserved material. Therefore, we have as yet little information as to the dynamic aspects of the budding of this type.

As has been briefly stated in a previous paper (NAKauchi, 1966a) the author found a Japanese polyclinid, Amaroucium yamazii, to propagate as Aplidium zostericola.

It was also found that Amaroucium yamazii is suitable material for the study of budding: The larvae are easily obtained, colonies easily cultured, and all the zooids clearly observable through their transparent tunic.

So, employing this material, an observation was made to fill the gap in our knowledge of the second type of budding.

In this paper the results of the observation are described more or less quantitatively. The following items are presented, for example; a) the timetable of budding, b) the variation of the number of buds produced in each budding, and c) the variation in the interval of two successive buddings.

Publ. Seto Mar. Biol. Lab., XVII (5), 309-328, 1970. (Article 20) 
The author is much indebted to Dr. Takasi Tokioka for his constant encouragement and for his valuable aid in publishing this work.

\section{Material and Method}

A colonial ascidian Amaroucium yamazii was used. This ascidian is hitherto recorded from Kii Sirahama (TокіокA, 1949), Sagami Bay (ТокіокA, 1953), and Usa (Nakauchi, 1966a). At Usa, Shikoku, it is commonly found in the shallow water of Uranouchi Bay, to which the Usa Marine Biological Station faces. It forms moderate-sized colonies encrusting the under surface of stones and floats for pearl culture.

Besides the method of budding, this ascidian is different from many species of Amaroucium in some features. The zooids have no long postabdomen. They form no system in the colony, and their common cloacal system is also inconspicuous. Because of the last feature, this species was originally described as a species belonging to the genus Ritterella by Tokioka (1949). But, the same author (1953) transfered this species to the genus Amaroucium on close examination of newly added completer materials. The structure of the zooid is described in detail by TокіокA $(1949,1953)$. It is to be noted, however, that some structures of zooids change as a zooid develops. The number of stigmatal rows is four in oözooids and usually five in blastozooids. In immature zooids the length of the postabdomen is shorter than that of the abdomen proper, but in mature zooids the former is slightly longer than the latter.

Observations were made at the Usa Marine Biological Station of the Kochi University from the 1st of November through the 28th of December in 1966. As a start of observation larvae were obtained from the colonies which had been reared on glass plates in a culture box floating on the bay. The colonies with mature zooids were placed in dishes with sea water, and larvae liberated from such colonies were collected in other dishes with sea water. The larvae were allowed to attach to glass slides $(65 \times 76 \mathrm{~mm})$ laid in the dishes. Many larvae attached to and metamorphosed on that glass slides. The slides with oözooids were then placed in a culture box in the bay, and the animals were cultured there. It may be said, therefore, that the materials were allowed to grow in the natural habitat. In order to follow the life history of the zooid, animals were brought to the laboratory once a day and observed under a stereomicroscope. The temparature of the ambient water near the culture box ranged from $14^{\circ} \mathrm{C}$ to $22^{\circ} \mathrm{C}$ during the period of the present observations.

\section{Results}

1. Development of oözooid

Plate XVI 1 shows a tadpole fixed in formalin. In life the trunk measures about $0.45 \mathrm{~mm}$ in length, and the tail $1.15 \mathrm{~mm}$ in length. 
The free swimming period of the larvae was not exactly determined. The period, however, seems not to extend over 20 hours, because on the next morning of the liberation usually no larvae were found to be swimming. In many cases metamorphosis was complete within the day of liberation.

A successive observation of each oözooid started usually on the 2nd day of development ${ }^{1}$ ). On the 2 nd day of development oözooids measure $0.8-0.9 \mathrm{~mm}$ in total length (Fig. 1A). The abdomen is almost equal to the thorax in length. The

A

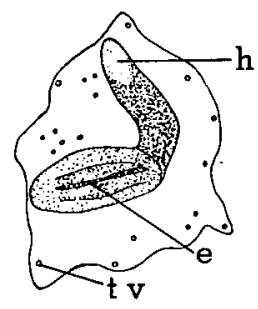

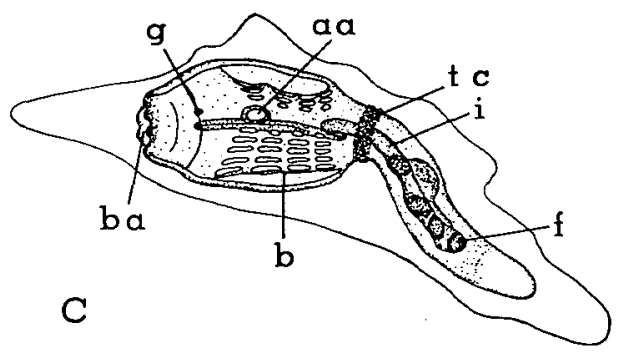

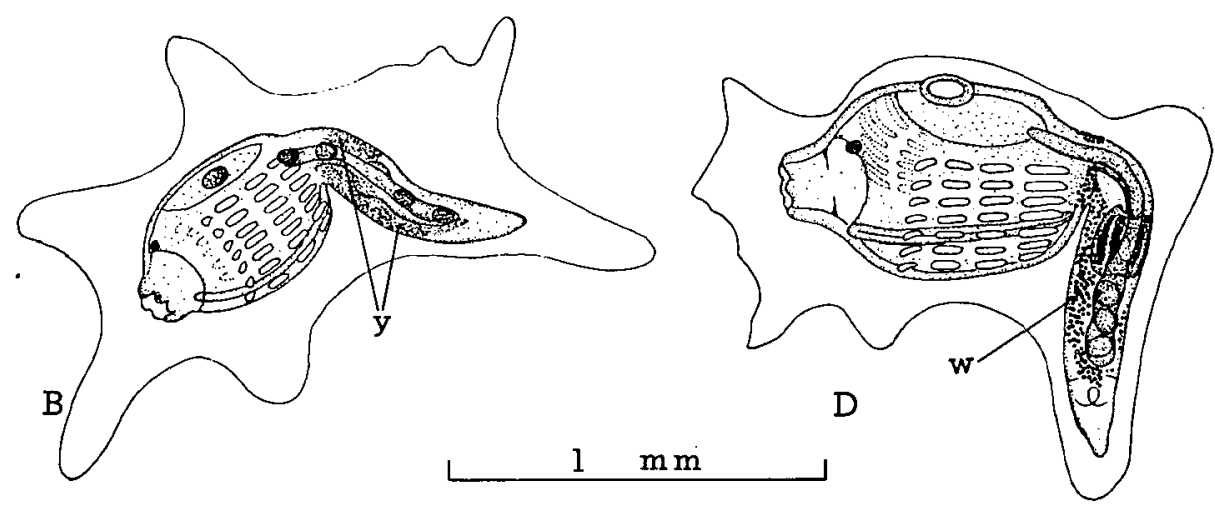

Fig. 1. Development of oözooid. A, Oözooid of the next day of metamorphosis. Ventral view (Material No. 111). B, A 2-day oözooid (No. 131). C, A 3-day oözooid (No. 131). D, A 5-day oözooid (No. 131). aa, atrial aperture; b, branchial sac; ba, branchial aperture; e, endostyle; f, fecal pellet; g, ganglion; h, heart; i, intestine; tc, tunic cell; tv, tunic vesicle; w, "white cell"; y, yolk particle.

thorax is not well expanded, and it looks milky white as a whole. Only the endostyle is clearly seen from the underside. Many yolk particles are packed in the abdomen, so most parts of the abdomen look pale yellow in color. Only the distal area is transparent, and a pulsating heart is observable there. At the periphery of the tunic about 20 tunic vesicles are clearly observed.

Feeding begins during the 2nd day of development. A 2-day oözooid ${ }^{2}$ ) usually

1) The 2nd day of development means the next day of the liberation of larvae, and it means also, in many cases, the next day of metamorphosis.

2) A 2-day oözooid means an oözooid observed on the 3rd day of development. 
has the expanded thorax, $0.6-0.7 \mathrm{~mm}$ long, and the abdomen, about $0.6 \mathrm{~mm}$ long, with functioning digestive tract containing fecal pellets (Fig. 1B). The number of stigmatal rows is four, and in each half row stigmata number between 5 (most posterior) and 7 (most anterior). Yolk granules, which were distributed throughout the abdomen on the previous day, are found mainly in the ventral side of the abdomen. The digestive tract is yellowish brown in color, and the folds of stomach are not clearly seen from the outside.

Fig. 1C shows a 3-day oözooid (The same specimen that is shown in Fig. 1B). It is shown in this figure that there is a belt-like structure surrounding the most anterior region of the abdomen. This structure is found in every zooid, and that

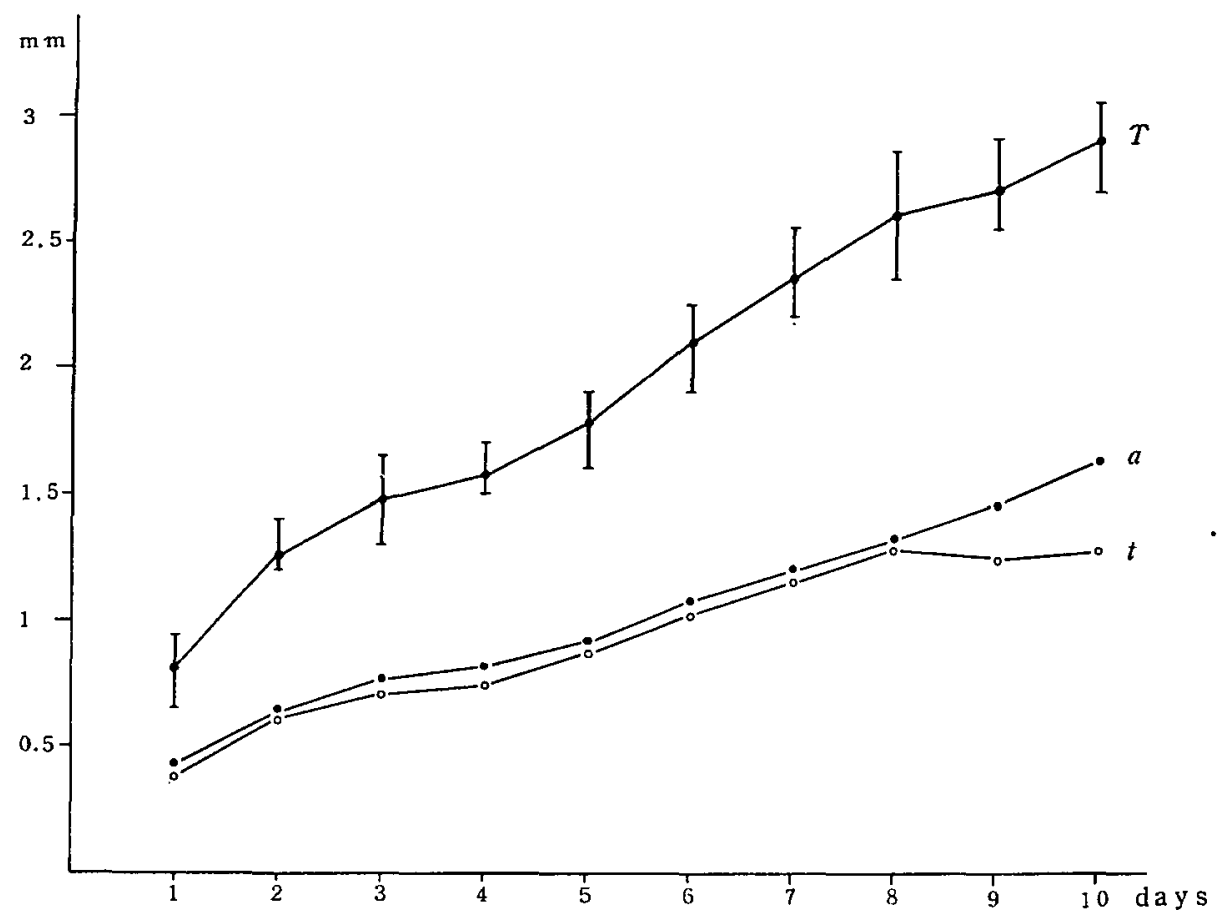

Fig. 2. Growth of oözooid. a, length of abdomen; $t$, length of thorax; $T$, total length.

is composed of many particles considered as a kind of tunic cells. As each particle is photo-reflective the structure looks a white belt of granular texture. As is shown later, these granular cells detach themselves from the zooid and migrate into the tunic at the time of budding.

Because a zooid which commenced to feed has all the organ systems except the reproductive organ, the development after this stage is concerned mainly with growth.

Fig. 2 shows the growth of the body length of oözooids. Although the length of the abdomen increases at a nearly constant rate throughout the oözooid stage, the length of the thorax reaches its maximum (ca $1.3 \mathrm{~mm}$ ) in about 8 days. The 
number of stigmatal rows does not increase during oözooid stage, but the number of stigmata in each row increases as the zooid grows. They number 9 or 10 in a full grown oözooid. The longitudinal muscles in the thorax number 9 or more on each side of a grown oözooid. The plications of the stomach which are not clearly observed in a young oözooid become clear in 4 or 5 days after metamorphosis, and number about 9 in a grown oözooid.

Throughout oözooid stage a zooid lies horizontally, and it does not erect its thorax. A zooid usually lies with its ventral side towards the substratum ("ventral substratum reaction", OkA and Usur, 1944).

In about five days after metamorphosis, with the disappearance of the yolk cells, "white cells" which are considered to be trophocytes commence to accumulate in the ventral region of the abdomen (Fig. ID). A few of "white cells" are also found in the dorsal region of the abdomen. The accumulation occurs mainly in the ventral region, from the middle level of the esophagus through the level close to the heart, and this continues till budding commences. So, the above-mentioned region of a fully grown oözooid looks milky white.

\section{Budding in oözooid}

1) Bud formation

Budding occurs after the oözooid stage of 10-16 days (Table 1). In other words, it occurs about the time when the length of the abdomen has reached $1.8 \mathrm{~mm}$.

Budding has some premonitory symptoms. The above-mentioned accumulation of the "white cells" may be counted among these symptoms. Following the accumulation of "white cells" an increase in the thickness of the epicardial wall commences, so the epicardium which is not observable from the outside in the young oözooid becomes visible in about 10 days after metamorphosis. The last, but the most manifest, symptom, the inflation of the posterior region of the esophagus, takes place about 3 days before the abdominal constrictions appear. The inflation of the esophagus means the initiation of development of new stomach, so it may be said that budding, at least in its wide sense, begins with this event. It may be defined incidentally that budding in a restricted sense begins with the appearance of abdominal constrictions. In this study the process of bud formation is divided into four stages, named Stage 0, I, II, and III, respectively (Table 2).

Stage 0 refers to the period between the initiation of esophageal inflation and the appearance of abdominal constrictions. In other words, Stage 0 begins with the initiation of budding in a wide sense and ends with the initiation of budding in a narrow sense. During this stage the growth of new stomach continues, so, when the abdominal constrictions appear the diameter of new stomach is nearly the same as that of old one. Though large, the new stomach has no folds characterizing the stomach of Amaroucium (Fig. 3A). Judging from food cord passing through the new stomach, it seems that the cavity of that region is not larger than that of the other 
Table 1. The span of one generation

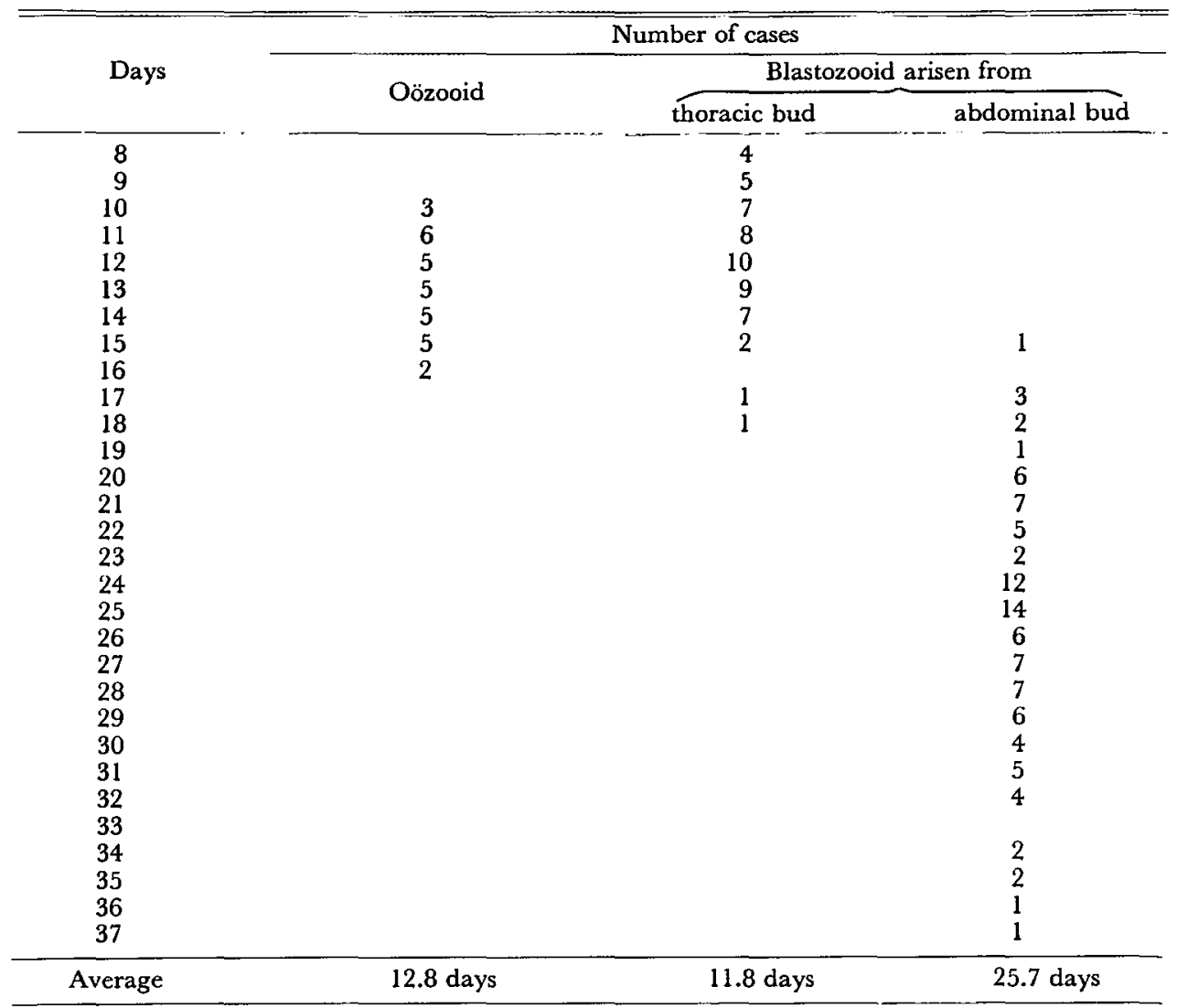

Table 2. Stages of strobila formation.

\begin{tabular}{|c|c|c|c|}
\hline Stage & & Events marking the stages & Other events \\
\hline $\begin{array}{l}0 \\
\text { (ca. } 3 \text { days) }\end{array}$ & $\left\{\begin{array}{l}\text { From } \\
\text { To }\end{array}\right.$ & $\begin{array}{l}\text { The beginning of inflation } \\
\text { of esophagus } \\
\text { The appearance of the } \\
\text { 1st constriction }\end{array}$ & $\begin{array}{l}\text { Accumulation of "white cell" } \\
\text { Increase in the thickness of epicardial wall }\end{array}$ \\
\hline$\stackrel{\text { I }}{(8-10 \text { hrs. })}$ & $\left\{\begin{array}{l}\text { From } \\
\text { To }\end{array}\right.$ & The beginning of beating & $\begin{array}{l}\text { Elongation of stomach } \\
\text { Appearance of the } 2 \text { nd and the subsequent } \\
\text { constrictions }\end{array}$ \\
\hline$\stackrel{\text { II }}{(3-4 \text { hrs. })}$ & $\left\{\begin{array}{l}\text { From } \\
\text { To }\end{array}\right.$ & $\begin{array}{l}\text { of new heart } \\
\text { The liberation of the } \\
\text { strobilating abdomen from }\end{array}$ & $\begin{array}{l}\text { Progress of constrictions by which epicardium } \\
\text { is divided into several parts } \\
\text { Slight contraction of the thorax of mother } \\
\text { zooid }\end{array}$ \\
\hline $\begin{array}{l}\text { III } \\
(4-5 \text { hrs. })\end{array}$ & $\left\{\begin{array}{l}\text { From } \\
\text { To }\end{array}\right.$ & $\begin{array}{l}\text { the mother zooid } \\
\text { The completion of the sepa- } \\
\text { ration of all strobilae }\end{array}$ & $\begin{array}{l}\text { Beginning of feeding of mother zooid } \\
\text { Isolation of each abdominal strobila }\end{array}$ \\
\hline
\end{tabular}


parts of esophagus, and it seems therefore that the region does not function as a stomach.

The external transformation begins with the appearance of an abdominal constriction at the level of the anterior region of the old stomach (Fig. 3A). This constriction may be safely called the "lst constriction", because it is first not only in its appearance but also its position. In other words, the 2 nd and succeeding constrictions always appear in antero-posterior order.

Stage $I$ is defined as the period between the appearance of the 1 st constriction and the initiation of the beating of new heart in the parent zooid. This stage lasts for 8-10 hours. In 1-2 hours after the appearance of the 1st constriction the 2 nd one

A

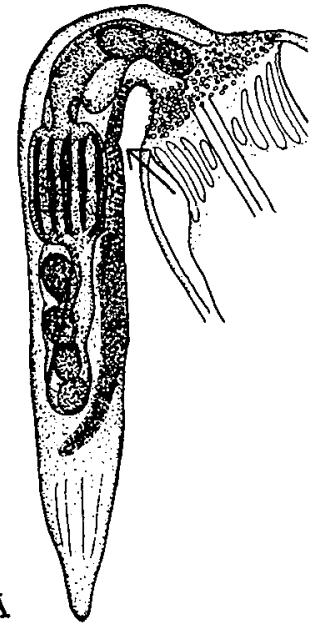

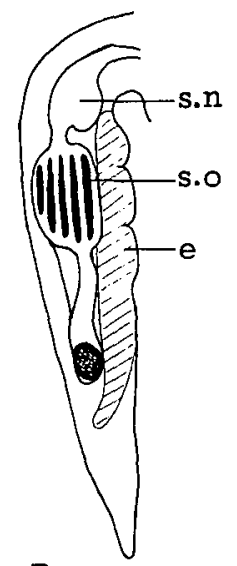

B

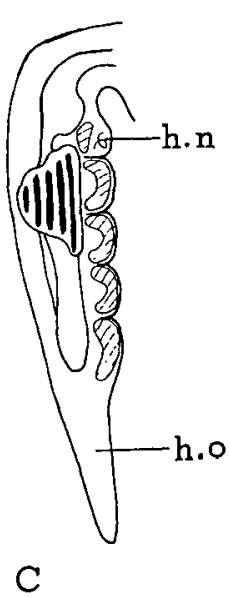

C

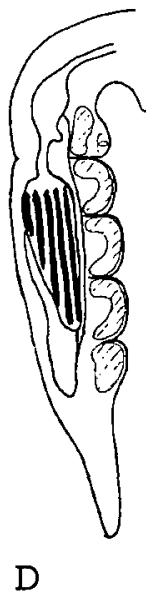

$\mathrm{D}$

Fig. 3. Appearance of constrictions accompanied with the elongation of the stomach. Semidiagramatic. A, Appearance of the 1st constriction. The arrow indicates the lst constriction. B, Stage I. C and D, Stage II. e, epicardium with trophocytes; h.n, new heart; h.o, original heart; s.n, new stomach; s.o, original stomach.

appears behind the 1st one at an interval of $0.17-0.20 \mathrm{~mm}$. The $3 \mathrm{rd}$ and the subsequent constrictions also appear at regular - time and space - intervals (Fig. 3B-D). All constrictions start from the ventral side and progress dorsally.

Between the appearance of the 2nd constriction and the appearance of the 3rd one, the elongation of the old stomach commences. The elongation is effected by the contraction of the intestine, so during this event the stomach is pulled posteriorly as a whole. Owing to this movement of the stomach the 1st constriction which appeared at the level of stomach does not cut it but cuts the esophagus.

The elongation of stomach lasts for 8-10 hours. During this elongation the 3rd, 4 th, and 5 th constrictions become clear. When appeared, each of above-mentioned constrictions is situated posterior to the elongating stomach. But, because the elongation progresses fast in comparison with the ingrowth of the epidermis, these 

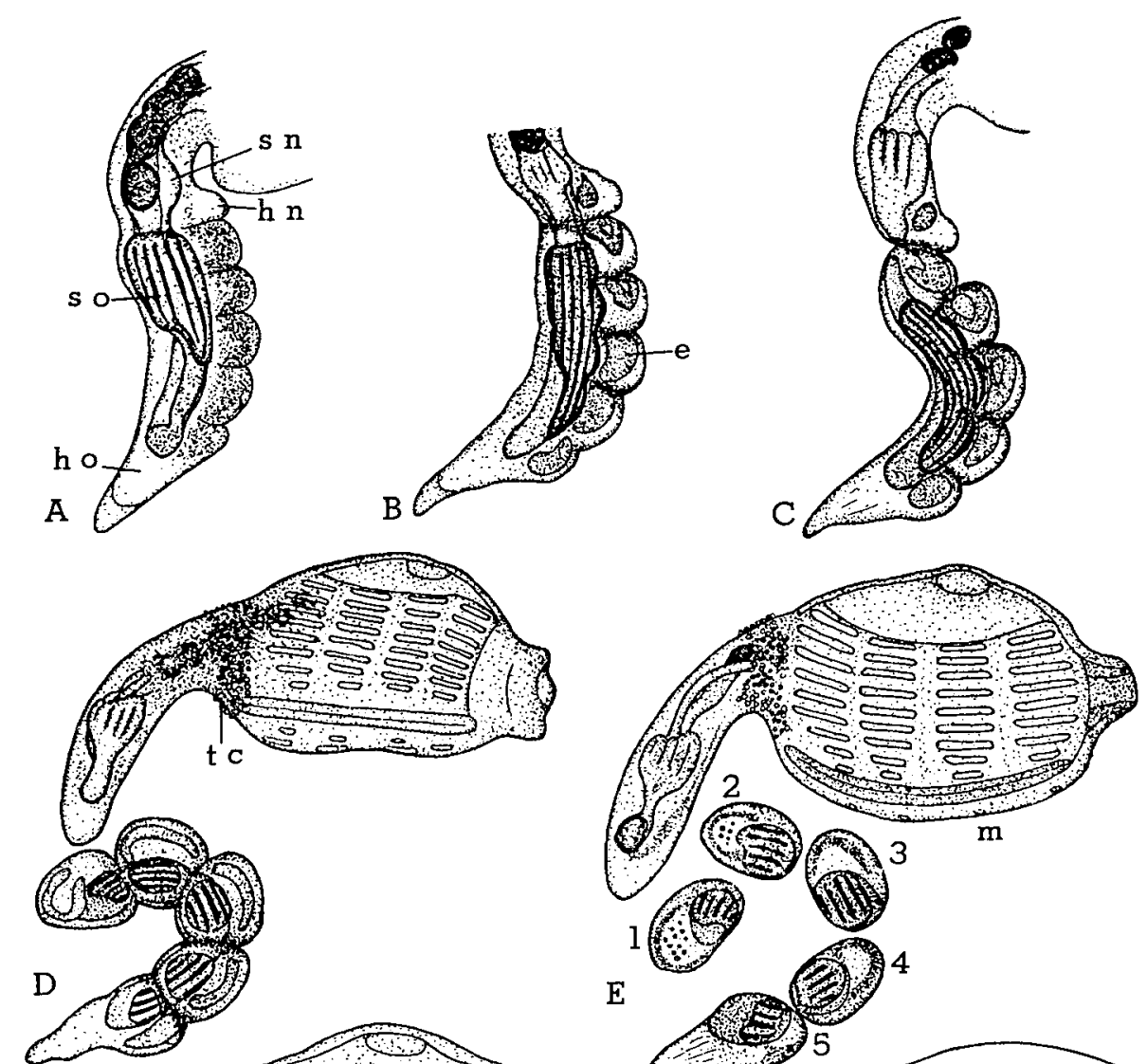

$\mathrm{E}$
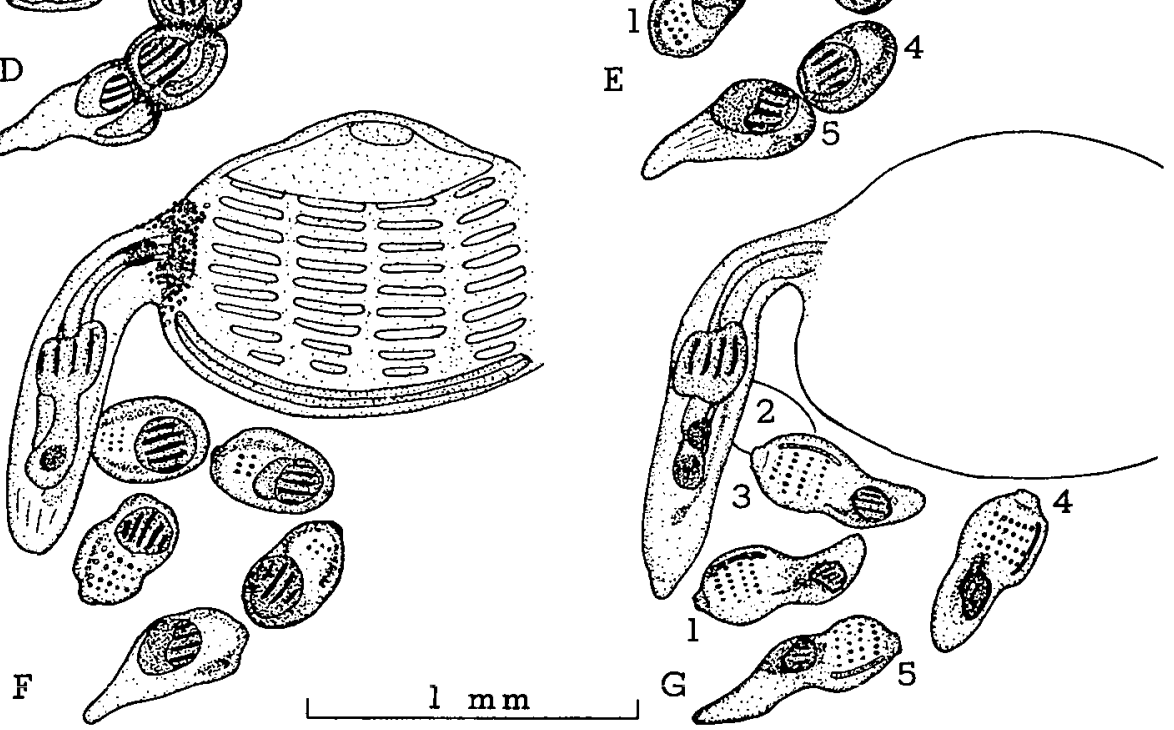

Fig. 4. Process of budding (Material No. 121). A, 11:50, 12. XI. 1966 Stage II. B, 14:15 Stage II. C, 14:40 Stage II. D, 17:00 Stage III. E, 20:00 Feeding of mother zooid begins. New heart of mother zooid beats normally. F, 22:10 G, 7:15, 13. XI New hearts of blastozooids beat slowly. m, mother zooid; tc, tunic cell; 1-5, 1st-5th bud. Explanation of other abbreviations as in Fig. 3. 
three constrictions cut the elongated stomach into four parts. So, when the number of constrictions (=the number of buds) is 5 or less, each bud contains a section of the old stomach. In some cases 6 or more buds are formed. When the number of buds is 6 , the 6 th bud sometimes lacks the stomachal tissue. When 7 or more buds are formed in the budding of blastozooids, the last bud always lacks the stomachal tissue. The variation in the number of buds will be presented later.

In 5-7 hours after the appearance of the 1st constriction, or about the time when the 3 rd constriction appears, a clear area develops in the ventral region just anterior to the 1st constriction (Fig. 4A), and within 5 hours this area develops into a beating heart. The pulsation begins about the time when the posterior end of the elongating stomach reaches the level of the 3rd constriction, and becomes rhythmical within 2 hours.

Stage II begins with the start of beating of the new heart. At this time the original heart is still beating normally. But, in about one hour after the new heart has started to beat rhythmically, the original heart somewhat reduces the pulse, and such irregular pulsation continues until the terminal bud, in which the original heart is situated, has been perfectly separated from the other buds.

It is to be noted that in this species the thorax of a budding zooid remains expanded throughout the period of bud formation, except a short period during Stage II. Feeding goes on even after the appearance of the 1st constriction and ceases at the latter period of Stage I. So, as the budding progresses the greater part of digestive tube becomes empty. The thorax, however, remains expanded for a few hours even after the feeding has ceased. A slight shrinkage of thorax occurs during Stage II, and the contracted thorax expands again after the isolation of its buds.

At the beginning of Stage II the constrictions have progressed as is shown in Fig. 4A, and the epicardial tube has been cut into several parts by the constrictions. During this stage the ingrowth continues and it cuts into the digestive tube. Finally the 1st constriction divides the budding zooid into the thorax (or mother zooid) and a strobilating abdomen (Fig. 4C). With this event Stage II terminates. Stage II usually lasts for 3-4 hours. During this stage the folds of new stomach become clear, and the prospective mid-intestine (=the esophageal region just anterior to the Ist constriction) becomes continuous with the ascending limb of digestive tube. In other words, the digestive system of mother zooid is almost complete when that zooid has been isolated from the strobilating abdomen.

Stage III refers to the period during which a strobilating abdomen separated from mother zooid is perfectly divided into several buds by a series of constrictions. The mother zooid becomes functional shortly after the separation of the old abdomen. The development of mother zooid will be described later together with that of its buds.

Each constriction becomes complete as a rule in regular order from the most anterior constriction to the most posterior one. All constrictions are completed in 
4-5 hours after the segmented abdomen has been separated from the mother zooid, and rapid growth of the produced buds follows it.

During this stage many of the tunic cells surrounding the neck of the abdomen become free from the zooid, and they migrate into the tunic as is shown in Fig. 5.

2) Bud development

(A) Mother zooid

Figs. 4D-4G show the development of both a mother zooid and its strobilae.

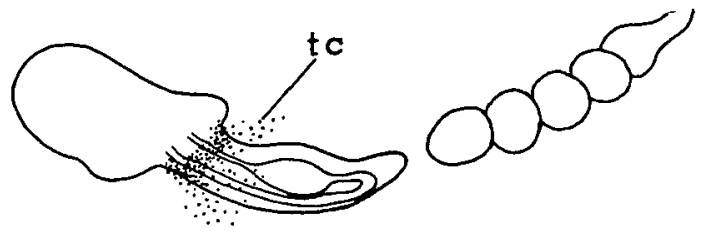

Fig. 5. Diffusion of tunic cells.

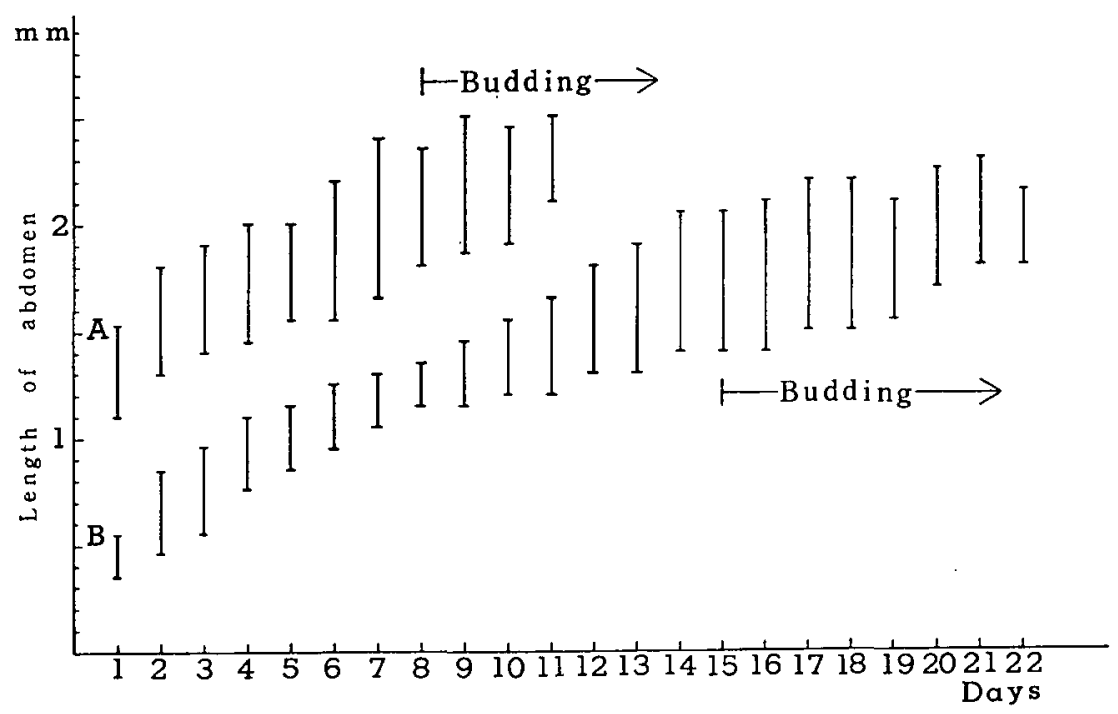

Fig. 6. Growth of blastozooids. Size of zooid is shown by the length of the abdomen. A, Mother zooid (or Zooid arisen from a thoracic bud). B, Blastozooid arisen from an abdominal bud. "Budding" indicates the next budding.

Shortly after a mother zooid gives off its old abdomen the thorax of mother zooid expands again. Feeding commences within 4 hours after separation. The abdomen grows rapidly, and in 4-7 days that region is perfectly restored to the original state in length. The color of stomach turns from yellow to orange, and in 4 days after separation it becomes difficult to distinguish the new stomach from the old one by color alone. The growth of mother zooid after budding is shown in Fig. 6 by the length of the abdomen. It takes only 8 days for some mother zooids to commence the next budding (Table 1). 
(B) Strobilae

As shown in Figs. $4 \mathrm{E}-\mathrm{G}$ the isolated strobilae develop at a great rate. The thoracic region becomes distinguishable from the abdominal region in 2 hours after the bud has been isolated (Fig. 4E). Within 12 hours after separation each bud becomes "merosomatous", and most of the structures in the thorax become recognizable. In most cases strobilae open to the exterior and begin to feed in 48-72 hours after being isolated. But, some strobilae develop more rapidly and they begin to feed about 40 hours after the isolation. At the beginning of feeding the zooid measures about $1.45 \mathrm{~mm}$ in total and $0.7-0.8 \mathrm{~mm}$ in abdominal length. It has 4 rows of stigmata as the oözooid. The 5-row stigmata characterizing blastozooids of this species are formed at the 2nd and subsequent buddings. Therefore, there is little difference between an oözooid and a blastozooid arisen from an oözooid. Young

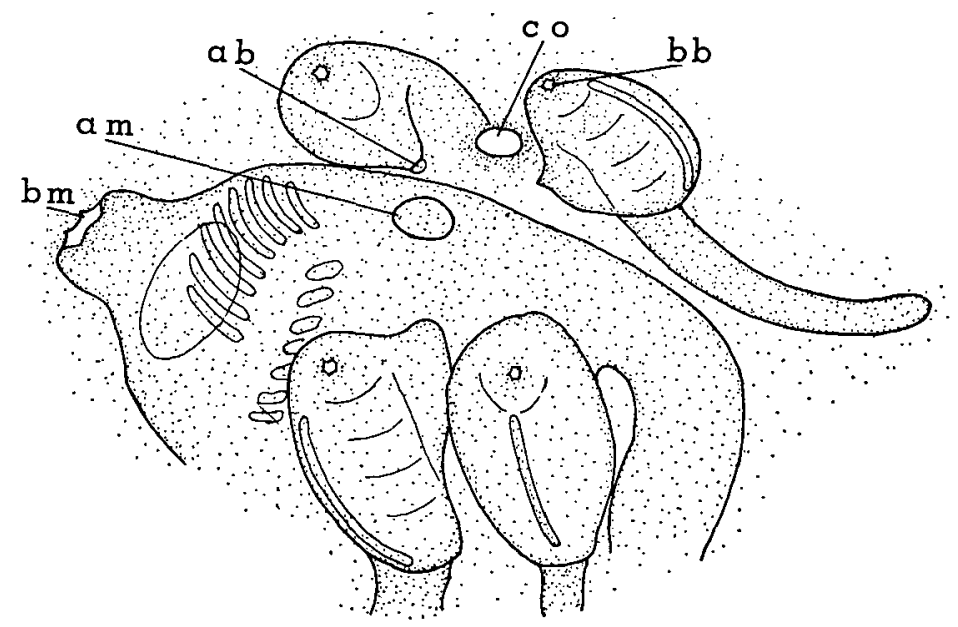

Fig. 7. A mother zooid and its four blastozooids. ab, atrial aperture of blastozooid; am, atrial aperture of mother zooid; bb, branchial aperture of blastozooid; bm, branchial ap. of mother zooid; co, common cloacal opening.

zooids are distinguishable from the mother zooid only by their size or by their more or less slender abdomen. Young blastozooids collect together around the atrial opening of the mother zooid with their dorsal side towards the opening (Fig. 7). The growth of strobilae is given in Fig. 6.

3. Budding in blastozooids

1) Budding in mother zooids

A mother zooid, or a blastozooid formed from a thoracic bud, begins the next budding usually 8-15 days after the 1st budding (Table 1). About 4 days after the preceding budding the epicardial tube and the aggregates of white cells become recognizable, and as the zooid ages the epicardial tube becomes conspicuous. 
Inflation of esophagus commences 5-10 days after the preceding budding, and new budding takes place, in most cases, 3-5 days after the esophageal inflation becomes clear.

2) Budding in blastozooids developed from abdominal buds

Blastozooids developed from abdominal buds begin the next budding after a variety of intervals (Table 1). Usually the next budding occurs at an interval of 20-32 days, but, in extreme cases, the next one occurs at 15 day or 37 day interval. Fig. 8 shows the interval of budding in the blastozooids arisen from a selected oözooid. The number of buds produced in each budding is also presented in the same figure.

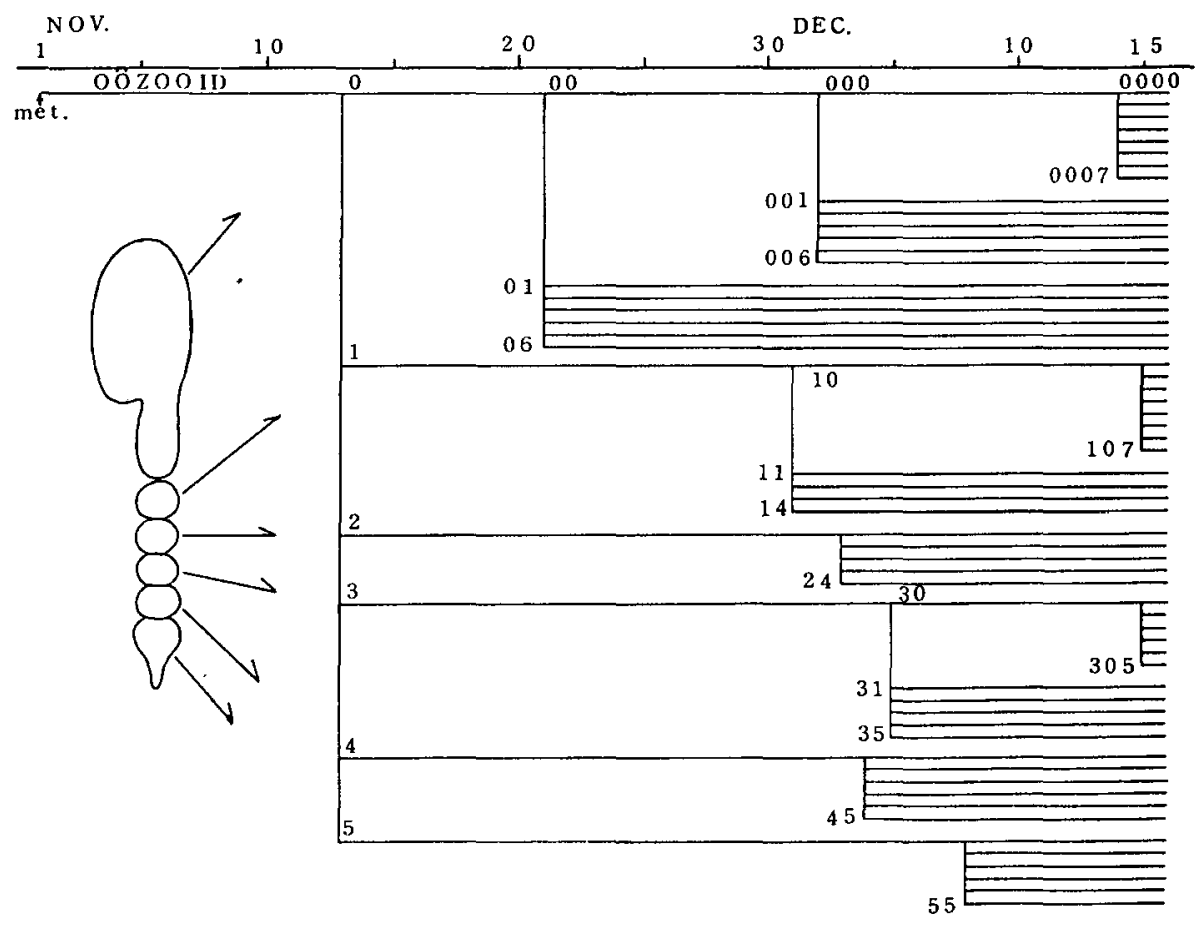

Fig. 8. Genealogy of the blastozooids originated from Oözooid No. 131. As to the naming of zooids see NakaUchi 1966a.

4. Number of the buds

The number of buds produced in each budding varies from 2 to 9 (Table 3). As a rule many buds are formed in the budding of the blastozooid developed from the thoracic bud, a few buds are produced in the budding of the oözooid, and intermediate number of buds are produced in the budding of the blastozooids formed from the abdominal buds. The relation between the age of budding zooid and the number of buds is shown in Table 4 . The relation between the abdominal length of oözooids measured on the previous day of budding and the number of 
Table 3. Number of buds produced in each budding.

\begin{tabular}{cccc}
\hline \multirow{2}{*}{ No. of buds } & Budding in oözooid & No. of cases & Budding in blastozooid developed from \\
\cline { 2 - 4 } & 3 & 3 & 3 \\
2 & 11 & 3 & 3 \\
3 & 11 & 7 & 35 \\
4 & 3 & 15 & 31 \\
6 & & 15 & 6 \\
7 & & 7 & 35 \\
9 & & 1 & 3 \\
\hline
\end{tabular}

Table 4. Relationship between the age of budding zooid and the number of buds.

(I) Budding in the blastozooids developed from thoracic buds (No. of cases)

\begin{tabular}{|c|c|c|c|c|c|c|c|c|c|c|c|}
\hline \multirow{2}{*}{$\begin{array}{l}\text { No. of } \\
\text { buds }\end{array}$} & \multicolumn{11}{|c|}{ Age of budding zooid (days) } \\
\hline & 8 & 9 & 10 & 11 & 12 & 13 & 14 & 15 & 16 & 17 & 18 \\
\hline 3 & 1 & & 1 & 1 & & & & & & & \\
\hline 4 & & & & 2 & 1 & & & & & & \\
\hline 5 & & 2 & & 3 & 1 & 1 & & & & & \\
\hline 6 & 1 & 2 & 3 & 2 & 2 & 2 & 2 & 1 & & & \\
\hline 7 & 1 & 2 & 2 & & 2 & 3 & 3 & 1 & & & 1 \\
\hline 8 & & & & & 3 & 2 & 1 & & & 1 & \\
\hline 9 & & & & & & & 1 & & & & \\
\hline
\end{tabular}

(II) Budding in the blastozooids developed from abdominal buds (No. of cases)

\begin{tabular}{|c|c|c|c|c|c|c|c|c|c|c|c|c|c|c|c|c|c|c|c|c|c|c|}
\hline \multirow{2}{*}{$\begin{array}{c}\text { No. of } \\
\text { buds }\end{array}$} & \multicolumn{22}{|c|}{ Age of budding zooid (days) } \\
\hline & 15 & 16 & 17 & 18 & 19 & 20 & 21 & 22 & 23 & 24 & 25 & 26 & 27 & 28 & 29 & 30 & 31 & 32 & 33 & 34 & 35 & 36 \\
\hline 2 & & & & & 1 & 2 & & & & & & & & & & & & & & & & \\
\hline 3 & & & & & & 2 & & & & & & & & & & & & & & & 1 & \\
\hline 4 & & & & 2 & & 1 & 2 & 1 & & 2 & & 1 & & & 1 & & & & & & & \\
\hline 5 & 1 & & 3 & & & 1 & 4 & 2 & 1 & 6 & 5 & & 2 & 2 & 2 & 1 & 1 & 4 & & & & \\
\hline 6 & & & & & & & 1 & 1 & & 2 & 7 & 4 & 4 & 4 & 1 & 2 & 2 & & & 2 & & 1 \\
\hline 7 & & & & & & & & & & & 2 & 1 & 1 & & 1 & 1 & & & & & & \\
\hline
\end{tabular}


buds is also shown in Fig. 9. It may be said that the number of buds has no close relationship either with the age of the budding zooids or with the length of the budding abdomen.

5. Number of the stigmatal rows

As is already mentioned, although the blastozooids formed directly from an oözooid have 4-row stigmata, the blastozooids formed in the 2nd and subsequent buddings of the mother zooid have 5-row stigmata. Blastozooids formed from blastozooids also have 5-row stigmata. So, the colony of this species is usually composed of a few zooids with 4-row stigmata (one of which is the "original zooid") and many blastozooids with 5-row stigmata. In this species the division of the stigmata,

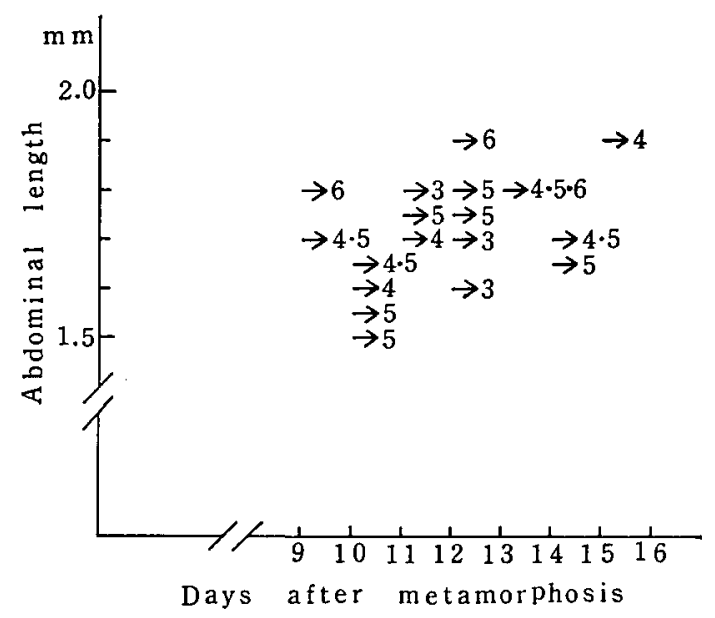

Fig. 9. Graph showing the relationship among the age of budding oözooid, the length of its abdomen, and the number of buds. The length of the abdomen is shown by the value measured on the previous day of budding.

by which the number of stigmatal rows increases, never takes place. Zooids with 5-row stigmata are formed asexually from the abdominal buds of 4-row or 5-row zooids, and they are 5-row from the beginning.

6. Growth of the colony

In this species budding takes place throughout the year. So, the colony grows constantly. The rate of growth, however, varies considerably with seasons and colonies. In summer a colony becomes large enough to cover one side of a glass slide (65 $\mathrm{mm} \times 76 \mathrm{~mm}$ ) within 70 days after metamorphosis. From autumn to winter, however, equivalent colonies are formed after the lapse of 4-5 months. The measurements of size of colonies are given in Table 5. 
Table 5. Growth of colony (winter).

\begin{tabular}{cccc}
\hline $\begin{array}{c}\text { Days after } \\
\text { metamorphosis }\end{array}$ & Extent (mm) & Colony 141 \\
\cline { 2 - 4 } & Colony 111 & Colony 121 & $5 \times 4$ \\
40 & $4 \times 4$ & $4 \times 3$ & $10 \times 7$ \\
55 & $10 \times 6$ & $7 \times 4$ & $9 \times 6$ \\
70 & $21 \times 9$ & $11 \times 6$ & $26 \times 12$ \\
90 & $28 \times 12$ & $16 \times 7$ & Divided into 3 col. \\
\hline
\end{tabular}

\section{Maturation}

In this species the zooids in young colonies have virtually no postabdomen. As the colony grows, a semitransparent region begins to develop between the posterior end of gut loop and the heart. The rudiments of testicular follicles then appear in the said region. In summer they appear about 3 weeks after metamorphosis. In winter, however, it takes 10 weeks or more for the appearance of the rudiments. The postabdomen becomes a little longer than the abdomen proper about the time when each of the testes has become clear (Fig. 10A). The testes develop, at first,

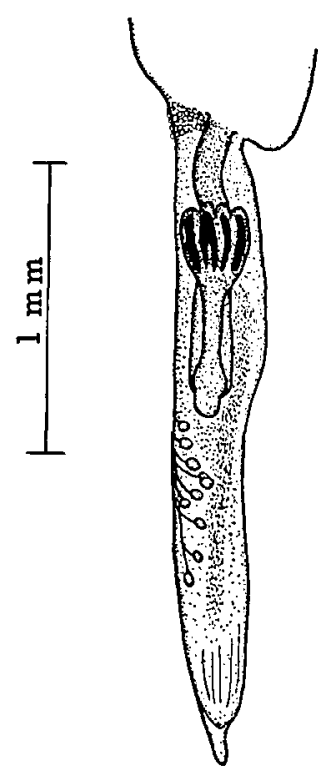

A

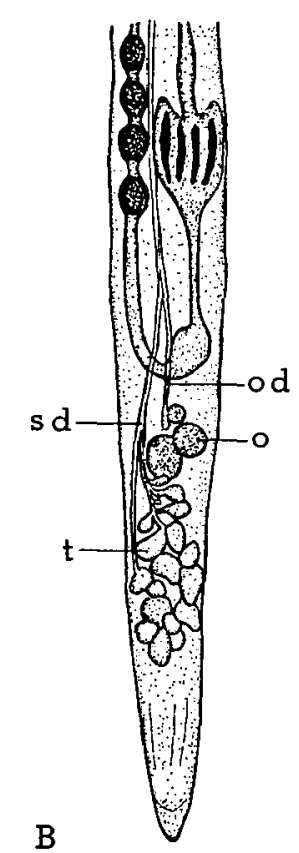

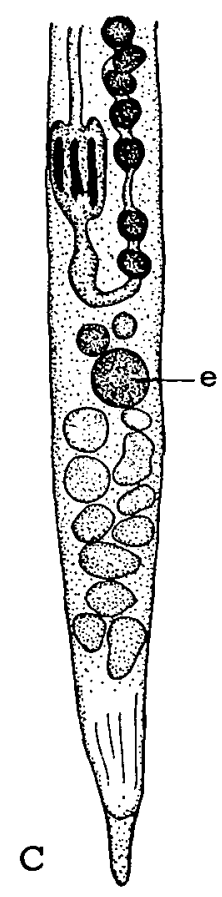

Fig. 10. Development of gonad. A, Appearance of the rudiment of testes. Lateral view (18. VI. 1964). B, Nearly matured zooid with cluster-like testicular follicles. Dorsal view (8. VII. 1964). C, Fully matured zooid. Ventral view (23. V. 1967). e, egg; o, ovary; od, oviduct; sd, spermiduct; $t$, testis. 
as a cluster (Fig. 10B), but their arrangement changes with age, and finally becomes biserial (Fig. 10G). The ovary appears after the testicular follicles have become clear. The colonies which arose at the beginning of November begin to liberate the tadpoles in the latter part of May following. On the other hand, the colonies which arose at the beginning of May liberate the larvae as early as the beginning of July.

In the mature colonies most of the zooids have the gonad, whereas they are not necessarily "aged" because of the repeated occurrence of budding. This fact indicates that the age of the zooid is not the basic factor influencing the maturation of the zooid. In fact, in these colonies, a newly formed blastozooid already has a short postabdomen, and it grows rapidly to form gonad in it. It may be said, therefore, that budding not always implies rejuvenation.

8. Budding in the mature zooid

Budding takes place even in mature zooids. It is to be noted that however long the postabdomen may be, no constrictions appear on the postabdominal region. So, throughout the life of a zooid it is the abdomen proper that strobilates. The postabdomen is always annexed in toto to the last abdominal strobila (Fig. 11).

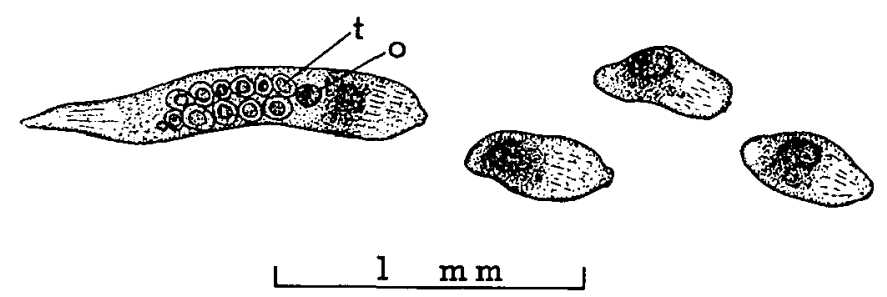

Fig. 11. Strobilae arisen from a mature zooid (2. IX. 1964). o, ovary; t, testis.

\section{Discussion}

The present study has shown that the budding method of Amaroucium yamazii is fundamentally the same with that of Aplidium zostericola. Their budding method resembles that of polycitorine ascidians. The present study has also shown the difference in budding method between Amaroucium yamazii and polycitorine ascidians. In Amaroucium yamazii nearly all buds contain the stomachal tissue, but in Polycitor (OKa and Usui, 1944) or in Archidistoma (NAKauchr, 1966b) the elongation of stomach is not so remarkable as in $A$. yamazii. In those polycitorine ascidians, besides the stomach, the esophagus elongates before the budding, and two or more constrictions cut that region. Some anterior buds, therefore, contain esophageal tissue instead of stomachal one. It may be said that in polycitorine ascidians the budding area extends more anteriorly than polyclinids.

In Amaroucium yamazii the new heart of the parent zooid becomes functional before 
the isolation of buds. In this point the budding of the present species resembles that of the clavelinid ascidian, Pycnoclavella stanleyi (Trason, 1963).

The mode of bud formation in the mature zooid which has a long postabdomen shows that in the present species the budding area is restricted to the abdomen proper. In other words, it has been shown that the postabdomen of this species has no budding potency. In most polyclinid ascidians buds are formed in the postabdomen (BERRILL, 1950) or in both the abdomen and postabdomen (NAKAuchi, 1966a). Even in the latter case, most of the buds are formed in the postabdomen. As to the budding potency of the postabdomen, therefore, Amaroucium yamazii is widely different from most species of Amaroucium. This fact brings forward a question as to the systematic position of the present species.

As is well known the genera Aplidium and Amaroucium are closely akin, and Amaroucium is sometimes treated as a subgenus of Aplidium (BERRILL, 1950) or a synonium of Aplidium (Mrllar, 1966).

Van Name (1945) defines Aplidium as follows: Aplidium is restricted to species having the colony attached by a broad base, rather stout zooids with few rows of stigmata and a comparatively short postabdomen, the stomach wall with a few deep folds extending throughout its length, the atrial aperture placed well back on the dorsal side, and testes in irregular group. According to Berrill (1950), Harrant (1933) defines Amaroucium as having a dorsal languet and Aplidium non.

As VAN NAMe (1945) and Berrill (1950) state, these criteria are* not satisfactory and in some cases they are absurd. On the basis of biserial arrangement of testes VAN NAme (1945) restored Aplidium zostericola (=pallidum) to Amaroucium in which Verrill originally placed it. This species has no atrial languet. So, if we adopt the criterion proposed by Harrant, it should be placed in Aplidium.

The present study shows that the arrangement of testes changes from irregular to biserial with the progress of maturation. BRIEN (1925) figures the testes of Aplidium zostericola as a cluster, but BERRILL (1950) states that the testes of the same species are usually but not always arrange serially along the sperm duct. These facts show that, as a taxonomic character, the arrangement of testes is not so valid unless the fully-matured specimens are examined.

It may be concluded, therefore, that the morphological differences between Aplidium and Amaroucium is too little to justify the generic separation.

On the other hand, from the embryological view point, Amaroucium yamazii, Aplidium zostericola and Ap. petrense form a group, and they are clearly distinguishable from the most of Amaroucium in which the postabdomen strobilates. This embryological difference may justify the generic separation of the former three species from usual Amaroucium. The study of embryological character, however, requires budding animals, and it makes the embryological character unpractical. But, the embryological character is replaceable by some morphological ones when the latter are closely related with the former. A. yamazii, A. zostericola, and A. petrense have 
commonly a relatively short postabdomen. The length of the postabdomen is a reliable taxonomic character unless very small colonies are examined. This character seems to be closely related with the mode of budding. Our knowledge of the budding in polyclinids is, however, too poor to conclude that all the polyclinids that have a relatively short postabdomen strobilize as Amaroucium yamazii. It may be concluded that, therefore, the review of the systematic position of the present species and the related ones needs more extensive study of the budding in polyclinid ascidians.

\section{Summary}

1. Life history of a colonial ascidian, Amaroucium yamazii was followed from the larval stage to the maturation stage, and, especially, the process of its budding was studied.

2. Unlike most polyclinid ascidians, buds of Amaroucium yamazii are produced in the abdomen proper. In breeding season the zooid has a postabdomen which is longer than the abdomen proper. Even in such a zooid buds are formed only in the abdomen proper, and the postabdomen is annexed in toto to the last abdominal bud.

3. Metamorphosis is completed within 20 hours after the liberation of larvae. Feeding begins during the 2nd day of development.

4. Budding occurs 10-16 days after metamorphosis. The most anterior constriction appears first, and following constrictions appear in antero-posterior order. The thorax remains expanded in the most period of budding. New heart (of mother zooid) becomes functional before the isolation of the budding abdomen, so a budding zooid has two functional hearts. Liberation of the strobilating abdomen from the mother zooid occurs 11-14 hours after the appearance of the 1st constriction. Isolation of each abdominal bud is completed within 20 hours after the appearance of the 1 st constriction.

5. Mother zooid begins to feed within 4 hours after the liberation of its budding abdomen. Mother zooid repeats budding at the interval of 8-18 days. Feeding of blastozooids begins $48-72 \mathrm{hrs}$. after isolation. Blastozooids formed from the abdomen repeat budding at the interval of 15-37 days.

6. The number of strobilae varies from 2 to 9 .

7. The number of stigmatal rows does not increase throughout the life of the zooid. Oözooids and the blastozooids formed from oözooids have a thorax with 4row stigmata. Zooids which have a thorax with 5-row stigmata is formed asexually from blastozooids.

8. Budding takes place throughout the year.

9. Maturation of a colony is attained in 2 (summer) -6 (winter) months after the metamorphosis of the original zooid. The testes appear as a cluster, but with the progress of maturation, they are rearranged biserially.

10. A taxonomical treatment is given on the genera Aplidium and Amaroucium. 


\section{REFERENCES}

BerrilL, N.J. 1950. The Tunicata with an account of the British species. London. Ray Society. Brien, P. 1925. Contribution à l'étude de la blastogénèse des Tuniciers. Bourgeonement chez Aplidium zosteriocla (Giard.). Arch. Biol., Vol. 35, pp. 155-205.

Kowalevsky, A. 1874. Ueber die knospung der Ascidien. Arch. Mikr. Anat., Vol. 10, pp. 441-470. Millar, R.H. 1962. Budding in the ascidian Aplidium petrense Michaelsen. Ann. Mag. Nat. Hist. Ser. 13, Vol. 5, pp. 337-340.

1966. Marine Invertebrates of Scandinavia, No. 1, Tunicata Ascidiacea. Oslo. Universitets Forlaget.

Nakauchi, M. 1966a. Budding and colony formation in the ascidian, Amaroucium multiplicatum. Jap. J. Zool., Vol. 15, pp. 151-172.

1966b. Budding and growth in the ascidian, Archidistoma aggregatum. Rep. Usa Mar. Biol. Sta., Vol. 13, pp. 1-10.

OKA, H. and M. Usui 1944. On the growth and propagation of the colonies in Polycitor mutabilis (Ascidiae compositae). Sci. Rep. Tokyo Bunrika Daigaku (Sec. B), Vol. 7, pp. 23-53.

Токіока, T. 1949. Contribution to Japanese ascidian fauna II. Notes on some ascidians collected chiefly along the coast of Kii Peninsula. Publ. Seto Mar. Biol. Lab., Vol. 1, pp. 39-64.

1953. Ascidians of Sagami Bay. Tokyo. Iwanami-Shoten.

Trason, W.B. 1963. The life cycle and affinities of the colonial ascidian Pycnoclavella stanleyi. Univ. Calif. Publ. Zool., Vol. 65, pp. 283-326.

Van Name, W.G. 1945. The North and South American ascidians. Bull. Amer. Mus. Nat. Hist., Vol. 84, pp. $1-476$. 


\section{EXPLANATION OF PLATES XVI-XVII}

Plate XVI. Amaroucium yamazii (TokıokA)

1 (Above). Tadpole fixed in formalin (24. XI. 1966).

2 (Below). 14-day oözooid. Underside seen through the glass plate (15. XI. 1966).

Plate XVII. Budding in an oözooid (No. 841). Underside seen through the glass plate.

3 (Above). 9:40, 25. XI. 1966.

4 (Below). 9:25, 26. XI. 1966. 
Publ. Seto Mar. Biol. Lab., XVII (5), 1970. PLATE XVI
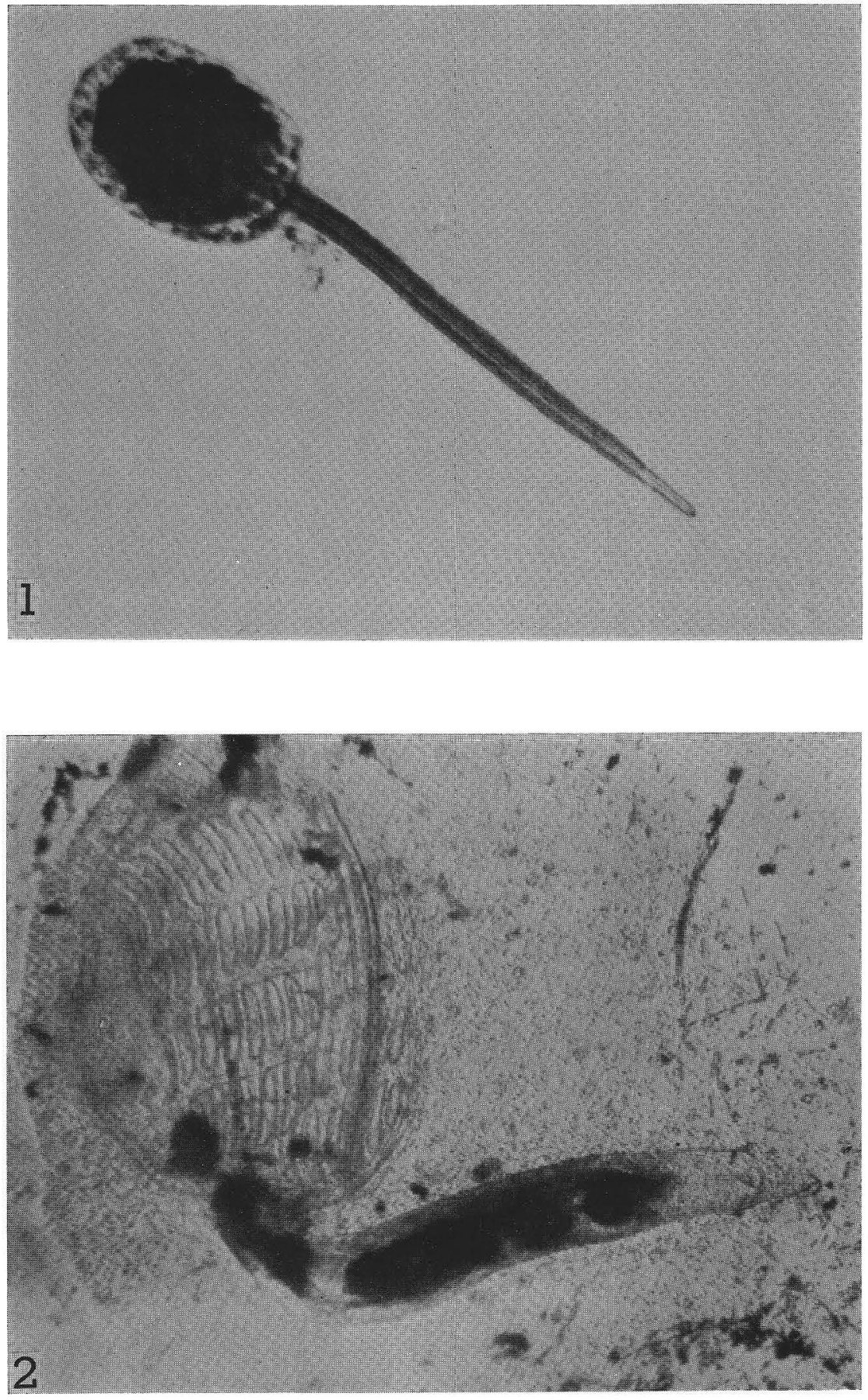

M. NaKauchi : Asexual Reproduction in Amaroucium 
Publ. Seto Mar. Biol. Lab., XVII (5), 1970 PLATE XVII
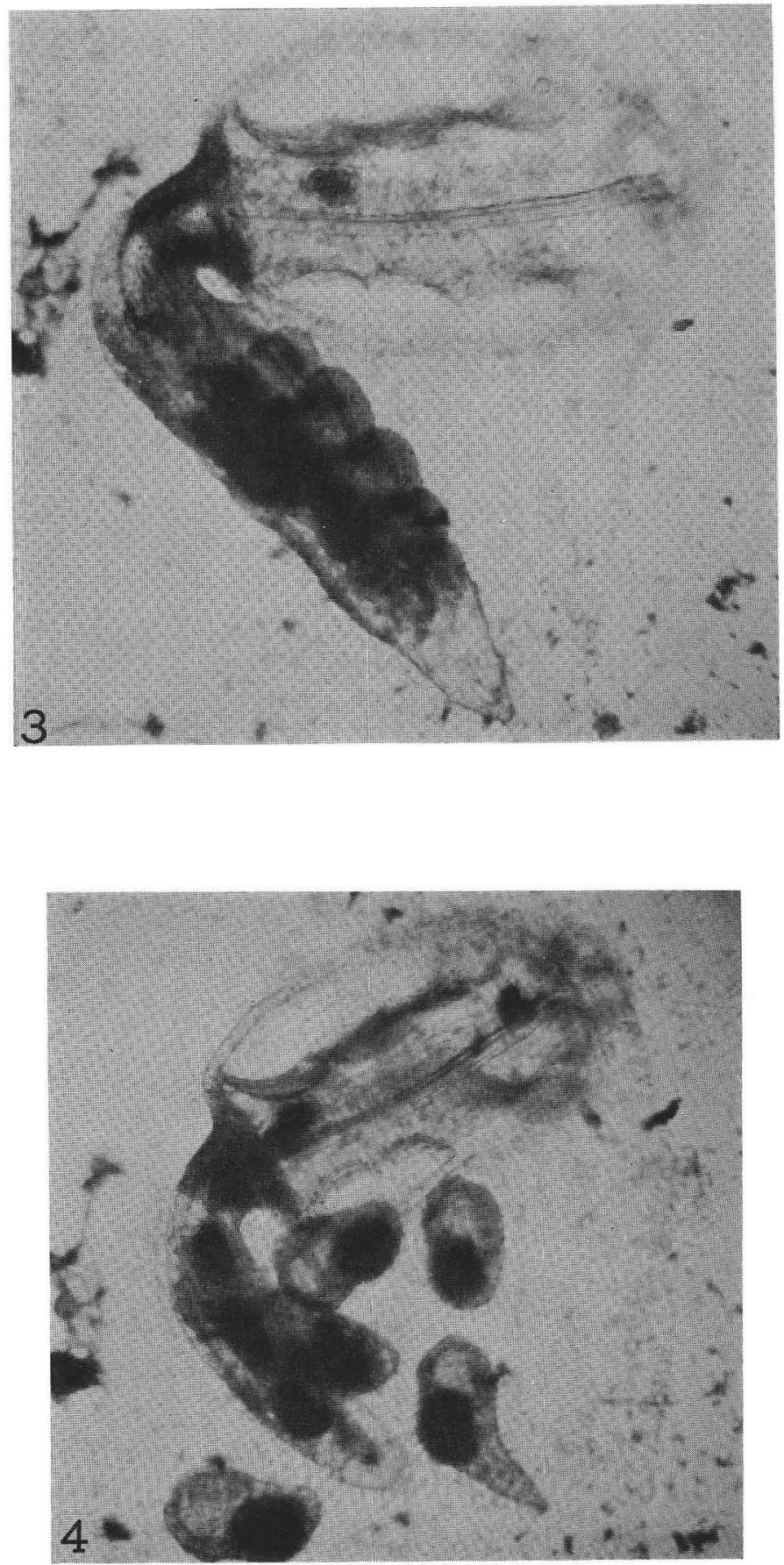

M. NAKAUCHI : Asexual Reproduction in Amaroucium 